\title{
Silver nitrate through flexible bronchoscope in the treatment of bronchopleural fistulae
}

\author{
Grigoris Stratakos, MD, ${ }^{\mathrm{a}}$ Lina Zuccatosta, MD, ${ }^{\mathrm{b}}$ Ilias Porfyridis, MD, ${ }^{\mathrm{a}}$ Michele Sediari, MD, \\ Charalambos Zisis, MD, FETCS, ${ }^{\mathrm{c}}$ Vasso Mariatou, MD, ${ }^{\mathrm{a}}$ Eleftherios Kostopoulos, MD, ${ }^{\mathrm{d}}$ \\ Argini Psevdi, MD, ${ }^{\mathrm{d}}$ Spyros Zakynthinos, $\mathrm{MD},{ }^{\mathrm{a}}$ and Stefano Gasparini, $\mathrm{MD}^{\mathrm{b}}$
}

\begin{abstract}
Objective: Bronchopleural fistula is a severe complication after pneumonectomy or lobectomy. Local application of silver nitrate to seal bronchopleural fistulae was reported once 25 years ago with considerable success but was never repeated. We aimed to develop and evaluate a concrete technique of applying silver nitrate through a flexible bronchoscope to treat bronchopleural fistulae in central airways.
\end{abstract}

\begin{abstract}
Methods: Consecutive patients with small $(\leq 5 \mathrm{~mm})$ bronchopleural fistulae in proximal airways were included in the study. After measurement of bronchopleural fistula size through a flexible videobronchoscopy, a standard bronchoscopic cytology brush covered with silver nitrate was passed through the working channel of the scope and was rubbed against the fistula's orifice producing blanching and edema on the mucosa. This procedure was repeated until closure of the fistula's orifice (treatment success) or absence of any tissue response after 2 bronchoscopic sessions (treatment failure).
\end{abstract}

Results: Of 16 patients referred, 5 were excluded from treatment because of large ( $>5 \mathrm{~mm}$ ) fistulae. Among the 11 treated patients (median fistula diameter $3 \mathrm{~mm}$, range $2-5 \mathrm{~mm}$ ), treatment failure was observed in 2 patients in whom treatment was attempted early ( 15 days postsurgery). In the remaining 9 patients, treatment success was achieved $(81.8 \%$ success rate) after a median of 2.5 (range 1-10) applications of silver nitrate. After $11(0.5-24)$ months of follow-up, no relapse was observed among successfully treated fistulae.

Conclusion: The local application of silver nitrate through a flexible bronchoscopic brush produced a burn and healing process on the mucosa of small bronchopleural fistulae of the central airways, leading to effective and lasting treatment in most cases.

Bronchopleural fistula (BPF), defined as communication between the bronchial tree and the pleural space, is a severe complication after pneumonectomy or lobectomy. It is associated with serious mortality ranging from $25 \%$ to $67 \%$ in various studies, with disabling morbidity occurring even more often. ${ }^{1,2}$ The incidence of this complication, although decreased in past decades after better understanding of the bronchial healing process, refinements of surgical techniques, and advances in postoperative intensive care, has been recently reported at $4.5 \%$ to $20 \%$ after pneumonectomy and $0.5 \%$ after lobectomy. ${ }^{1-5}$

Even small fistulae can produce immediate devastating sequelae, namely, chronic purulent infection, empyema,

\footnotetext{
From the Critical Care and Respiratory Division, ${ }^{\text {a }}$ University of Athens, Athens, Greece; Pulmonary Diseases Unit, Department of Internal Medicine, Immunoallergic and Respiratory diseases, ' “'Ospedali Riuniti, , Ancona, Italy; and Thoracic Surgery Department ${ }^{\mathrm{c}}$ and Anesthesiology Department, " "Evaggelismos" Hospital, Athens, Greece.

Received for publication July 17, 2008; revisions received Sept 20, 2008; accepted for publication Oct 26, 2008; available ahead of print Feb 23, 2009.

Address for reprints: Charalambos Zisis, MD, FETCS, Department of Thoracic Surgery, "Evangelismos" Hospital 45-47, Ipsilantou St, 10675 Athens, Greece (E-mail: chzisis@hol.gr).

J Thorac Cardiovasc Surg 2009;138:603-7

$0022-5223 / \$ 36.00$

Copyright (c) 2009 by The American Association for Thoracic Surgery

doi:10.1016/j.jtcvs.2008.10.054
}

pneumothorax, and respiratory insufficiency often requiring mechanical ventilation. ${ }^{6}$

Successful BPF treatment requires aggressive control of infection, adequate drainage of the chest cavity, closure of the fistula, and obliteration of the pleural space. ${ }^{4}$ Scientific evidence for the management of BPF is scarce and based mainly on experts' opinion or case reports. ${ }^{5-9}$ Therapeutic options range from extensive surgical procedures, including transsternal mediastinal closure of the BPF (Abruzzini technique), repetition of thoracotomy, thoracoplasty, or chest wall fenestration, to several more conservative bronchoscopic techniques attempting to seal abnormal communication. ${ }^{5,6}$ Surgical maneuvers include debridement and closure with buttressing of a pedicled omental or muscle flap. The therapeutic strategy is dependent on the clinical, oncologic, and nutritional status of the patient and the size of the fistula, but the tendency in the decision making process is, if feasible, toward a less interventional approach. For that reason, there are a variety of sophisticated alternatives that have been reported in the recent surgical and interventional literature.

In a recent meta-analysis ${ }^{7}$ of 85 post-pneumonectomy BPFs reported in the literature as treated endoscopically, the question was addressed whether the bronchoscopic approach was effective compared with a conventional rethoracotomy. There was $40 \%$ mortality and a $30 \%$ cure rate 


\section{Abbreviation and Acronym \\ $\mathrm{BPF}=$ bronchopleural fistula}

using a wide range of bronchoscopic procedures that were broadly categorized as (a) tracheobronchial stenting, ${ }^{8}$ (b) occlusion with glue or other chemical or biological sealants, ${ }^{9,10}$ and (c) procedures to induce scar tissue formation. ${ }^{11-14}$ The latter category, mainly referring to neodymium-doped yttrium aluminium garnet laser application, ${ }^{11}$ submucosal injections of the vein sclerosant polidocanol, ${ }^{12}$ and submucosal alcohol injections, ${ }^{13}$ has shown promising results with resolution of small $(<3 \mathrm{~mm})$ $\mathrm{BPF}$ in central airways in a proportion ranging from $33 \%$ to $58 \%$ with relatively few complications and low mortality.

In 1984, a Danish group published their experience on successful closing of at least 10 BPFs by repeated application of silver nitrate using the rigid bronchoscope combined with effective surgical drainage when necessary. ${ }^{14}$ Silver nitrate application produced burn-related scar formation and granulation that was able to occlude fistulae in the majority of their cases. Since then, although the applied technique was only vaguely described, this process has been quoted and cited in all reviews on the subject but was never repeated by either rigid or flexible bronchoscopy. ${ }^{5-7}$

Facing such a severe surgical complication for which a gold standard established treatment of choice is missing, and taking into account the promising results of the sole report on silver nitrate use with rigid bronchoscopy, ${ }^{14}$ we aimed to investigate the value of silver nitrate when applied on BPFs with flexible bronchoscopy. More specifically, we aimed to develop and evaluate a concrete and practical technique of applying silver nitrate on the bronchial mucosa through a flexible videobronchoscope intending to treat small $(\leq 5 \mathrm{~mm})$ BPFs in central airways. We also aimed to prospectively evaluate the effectiveness and safety of such a technique on long-term follow-up. We hypothesized that repeated use of this technique would result in effective and safe closure of small $(\leq 5 \mathrm{~mm}$ at maximum diameter $)$ BPFs in proximal airways.

\section{PATIENTS AND METHODS}

Approval from the ethical committee of our institutions was obtained to study the bronchoscopic application of silver nitrate with the purpose of treating small proximal BPF.

\section{Study Group}

All consecutive patients with post-pneumonectomy or post-lobectomy BPFs, referred after interdisciplinary counseling to the Critical Care and Respiratory Division of Athens University (Greece) and to the Pulmonary Diseases Unit of Ancona Hospital (Italy) for endoscopic treatment, were eligible for the study. Exclusion criteria were peripheral location (beyond bronchoscopic reach) or large size of the fistula $(>5 \mathrm{~mm})$. In all patients in whom hydropneumothorax was evident on chest $\mathrm{x}$-ray, the pleural drain-

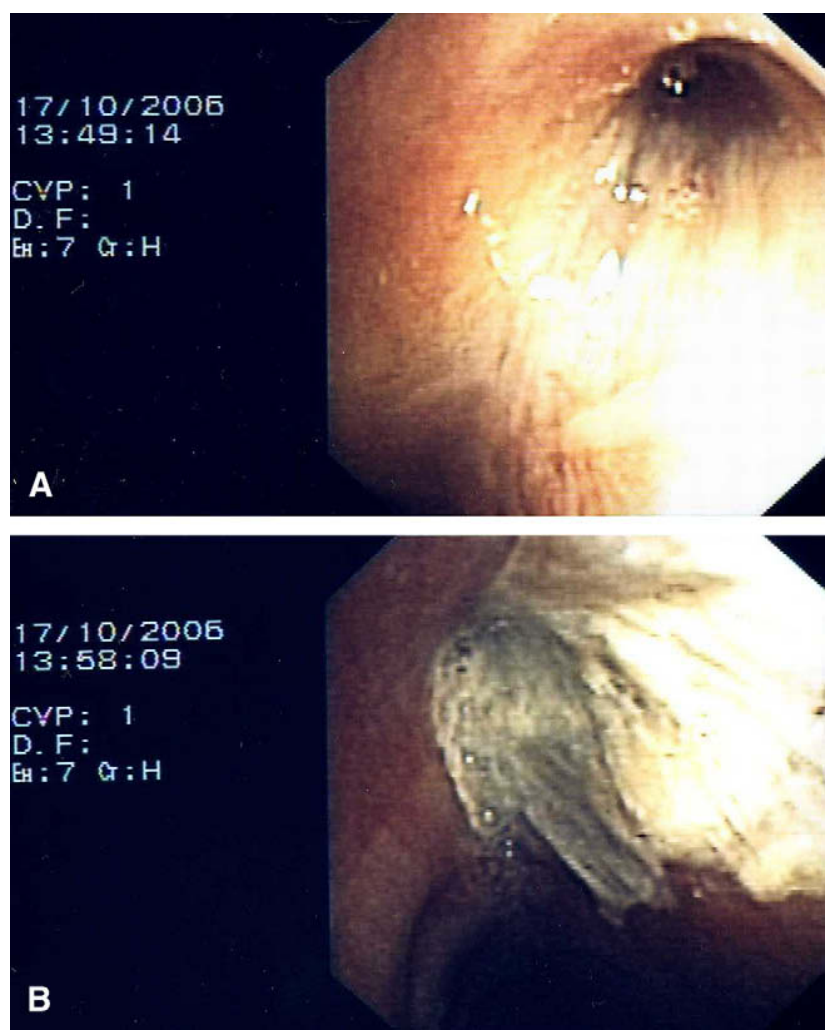

FIGURE 1. A, Small $(3 \mathrm{~mm})$ BPF of the left main bronchus, approximately $0.5 \mathrm{~cm}$ lower than the main carina (case 1). B, After application of silver nitrate, burn of the bronchial mucosa is manifested with a characteristic blanching effect of the mucosal surface and scar formation resulting in complete occlusion of the abnormal communication.

age tube was placed at the affected side before bronchoscopic evaluation. All patients gave written informed consent.

\section{Procedure}

Patients underwent flexible videobronchoscopy under conscious sedation (midazolam, $2.5 \mathrm{mg}$ ) to visualize and measure the abnormal communication. BPF size of $5 \mathrm{~mm}$ or less was estimated with a standard bronchoscopic biopsy forceps measuring $5 \mathrm{~mm}$ at its full opening. The first attempt to treat BPF with application of silver nitrate was undertaken during the initial diagnostic bronchoscopy.

A standard bronchoscopic cytology brush was especially prepared to act as a silver nitrate applicator. Conventional silver nitrate rods melt and directly turn to a liquid phase when exposed to flame. Drops of melted silver nitrate material were allowed to evenly cover a standard cytology bronchoscopic brush and solidify. This process was done repeatedly until the entire surface of the brush was covered with silver nitrate, taking care not to increase its diameter excessively, which would impede the brush from passing through the 3.2-mm caliber working channel of an interventional videobronchoscope (Olympus BF-XT160, Olympus America Inc, Melville, NY). This preparation was undertaken by a nurse in an adequately aerated room under aspiration to avoid inspiration of harmful vapors of silver nitrate.

The bronchoscope was then positioned as close as possible to the orifice of the fistula, and with continuous aspiration the mucosa was dried of secretions. Then, the silver nitrate applicator was passed through the working channel of the bronchoscope and was gently rubbed against the mucosal borders of the fistula. If excessive force was exerted at this point, a piece 


\begin{tabular}{|c|c|c|c|c|c|c|c|c|c|c|}
\hline \multirow[b]{2}{*}{$\begin{array}{c}\text { Patient } \\
\text { No. } \\
\end{array}$} & \multirow[b]{2}{*}{$\begin{array}{l}\text { Age } \\
(y)\end{array}$} & \multirow[b]{2}{*}{ Gender } & \multirow[b]{2}{*}{$\begin{array}{l}\text { Surgical } \\
\text { treatment }\end{array}$} & \multicolumn{7}{|c|}{ Bronchopleural fistulae } \\
\hline & & & & Location & $\begin{array}{c}\text { Size } \\
(\mathbf{m m})\end{array}$ & $\begin{array}{c}\text { Time from } \\
\text { surgery } \\
\text { (mo) } \\
\end{array}$ & $\begin{array}{c}\text { Complications; } \\
\text { symptoms } \\
\end{array}$ & $\begin{array}{c}\text { Bronchoscopy } \\
\text { sessions (n) } \\
\end{array}$ & $\begin{array}{c}\text { Outcome of } \\
\text { treatment }\end{array}$ & $\begin{array}{c}\text { Follow up } \\
\text { (mo); cause } \\
\text { of death }\end{array}$ \\
\hline 1 & 53 & Male & $\begin{array}{l}\text { Right PNY for } \\
\text { NSCLC }\end{array}$ & $\begin{array}{l}\text { LMB adjacent } \\
\text { to the stump }\end{array}$ & 3 & 12 & $\begin{array}{l}\text { Empyema; fever, } \\
\text { cough, purulent } \\
\text { expectoration }\end{array}$ & 1 & $\begin{array}{r}\text { Definitive } \\
\text { closure }\end{array}$ & $\begin{array}{c}\text { 16; pulmonary } \\
\text { embolism }\end{array}$ \\
\hline 2 & 71 & Male & $\begin{array}{l}\text { Left upper } \\
\text { LBY for } \\
\text { actinomycoma }\end{array}$ & Stump & 2 & 84 & $\begin{array}{l}\text { Empyema; fever, } \\
\text { cough, purulent } \\
\text { expectoration }\end{array}$ & 2 & $\begin{array}{r}\text { Definitive } \\
\text { closure }\end{array}$ & 10 \\
\hline 3 & 57 & Male & $\begin{array}{l}\text { Left PNY for } \\
\text { NSCLC }\end{array}$ & Stump & 3 & 6 & $\begin{array}{l}\text { Pyo-pneumothorax; } \\
\text { cough }\end{array}$ & 1 & $\begin{array}{r}\text { Definitive } \\
\text { closure }\end{array}$ & 8 \\
\hline 4 & 65 & Male & $\begin{array}{l}\text { Left PNY for } \\
\text { mesothelioma }\end{array}$ & Stump & 5 & 3 & $\begin{array}{l}\text { Purulent } \\
\text { expectoration }\end{array}$ & 10 & $\begin{array}{r}\text { Definitive } \\
\text { closure }\end{array}$ & 12 \\
\hline 5 & 72 & Male & $\begin{array}{l}\text { Right PNY for } \\
\text { NSCLC }\end{array}$ & Stump & 3 & 2 & $\begin{array}{l}\text { Purulent } \\
\quad \text { expectoration }\end{array}$ & 6 & $\begin{array}{r}\text { Definitive } \\
\text { closure }\end{array}$ & 16 \\
\hline 6 & 68 & Male & $\begin{array}{l}\text { Right PNY for } \\
\text { NSCLC }\end{array}$ & Stump & 4 & 0.5 & $\begin{array}{l}\text { Fever and } \\
\text { productive } \\
\text { cough }\end{array}$ & 1 & Failure & - \\
\hline 7 & 74 & Male & $\begin{array}{l}\text { Right upper LBY } \\
\text { for NSCLC }\end{array}$ & Stump & 3 & 0.5 & Empyema; fever & 1 & Failure & - \\
\hline
\end{tabular}

NSCLC, Non-small cell lung cancer; $P N Y$, pneumonectomy; $L B Y$, lobectomy; $L M B$, left main bronchus.

of the silver nitrate material on the brush could be detached and dropped freely on the stump mucosal surface, requiring immediate removal by aspiration or forceps. After 5 seconds of contact of the brush with the bronchial mucosa, the applicator was retracted and bronchoscopists could inspect the bronchial wall. Applications were continued in a circumferential way in 5second sessions until blanching and edema of the mucosa appeared all around the fistula's orifice as evidence of burn damage on the bronchial wall (Figure 1).

\section{Monitor and Follow-up}

Bronchoscopy was repeated 2 to 3 days later to inspect the early cicatricial effect of the silver nitrate application and to evaluate sealing of the abnormal communication. If effective sealing was not accomplished, the procedure was repeated up to 10 times at intervals of 5 to 7 days. When effective sealing was achieved (treatment success), the patient was discharged and reexamined bronchoscopically in 1 month and 6 months' time for follow-up. Treatment failure was defined as absence of any tissue response (ie, blanching and edema of the mucosa) or increase of the size of the fistula after 2 therapeutic bronchoscopic sessions. In such cases, no further attempt to use this approach was undertaken.

\section{RESULTS}

Between January 1, 2006, and December 31, 2007, 16 patients with post-pneumonectomy or post-lobectomy BPFs were referred to the interventional pulmonology department of our institutions for endoscopic management instead of surgical approach. Five of them were excluded: One patient had a surgical complication (the presence of a cartilage piece in the suture line of the stump), and 4 patients had large ( $>5$ $\mathrm{mm}$ ) fistula orifices.

Eleven patients were enrolled in the study (Table 1). All were male, with a median age of 69.5 years (range, 48-78 years). Seven patients had undergone pneumonectomy and
4 patients had undergone lobectomy for malignant (9 patients, 7 with non-small cell lung cancer and 2 with mesothelioma) and nonmalignant ( 2 patients, 1 with abscessed mycetoma caused by Actinomyces israeli and 1 with bronchiectasis) diseases. Surgical margins in patients with malignant disease were proven negative at the time of surgery.

The median diameter of the BPF orifice was $3 \mathrm{~mm}$ (range 2-5 $\mathrm{mm}$ ), and the time from surgical intervention to diagnosis was $3(0.5-84)$ months. The treatment procedure required 2.5 (1-10) bronchoscopic sessions with silver nitrate applications and resulted in definite BPF closure in 9 patients $(81.8 \%$; treatment success) and BPF closure failure in 2 patients (18.18\%; treatment failure). More specifically, patients 1 and 3 required only 1 session of silver nitrate application because in subsequent bronchoscopies complete cicatricial healing of the fistula with granulation tissue formation was evident (Figure 1). Patients 2, 4, 5, and 8 to 11 required repeated applications of silver nitrate (2-10) until complete closure of the fistula orifice and healing were observed (Figure 2). Patients 6 and 7 were treated early (15 days) postsurgery. Bronchoscopic application of silver nitrate in these 2 patients failed to produce healing and closure of the fistula. The application increased the size of the fistula's orifice and led to deterioration of the patients' condition. Two patients were referred back to thoracic surgeons for surgical treatment.

After a median follow-up of 11 months (range, 0.5-24 months), no relapse occurred in the 9 successfully treated patients. Two of these patients died of reasons unrelated to BPF 0.5 and 16 months after bronchoscopic treatment. 

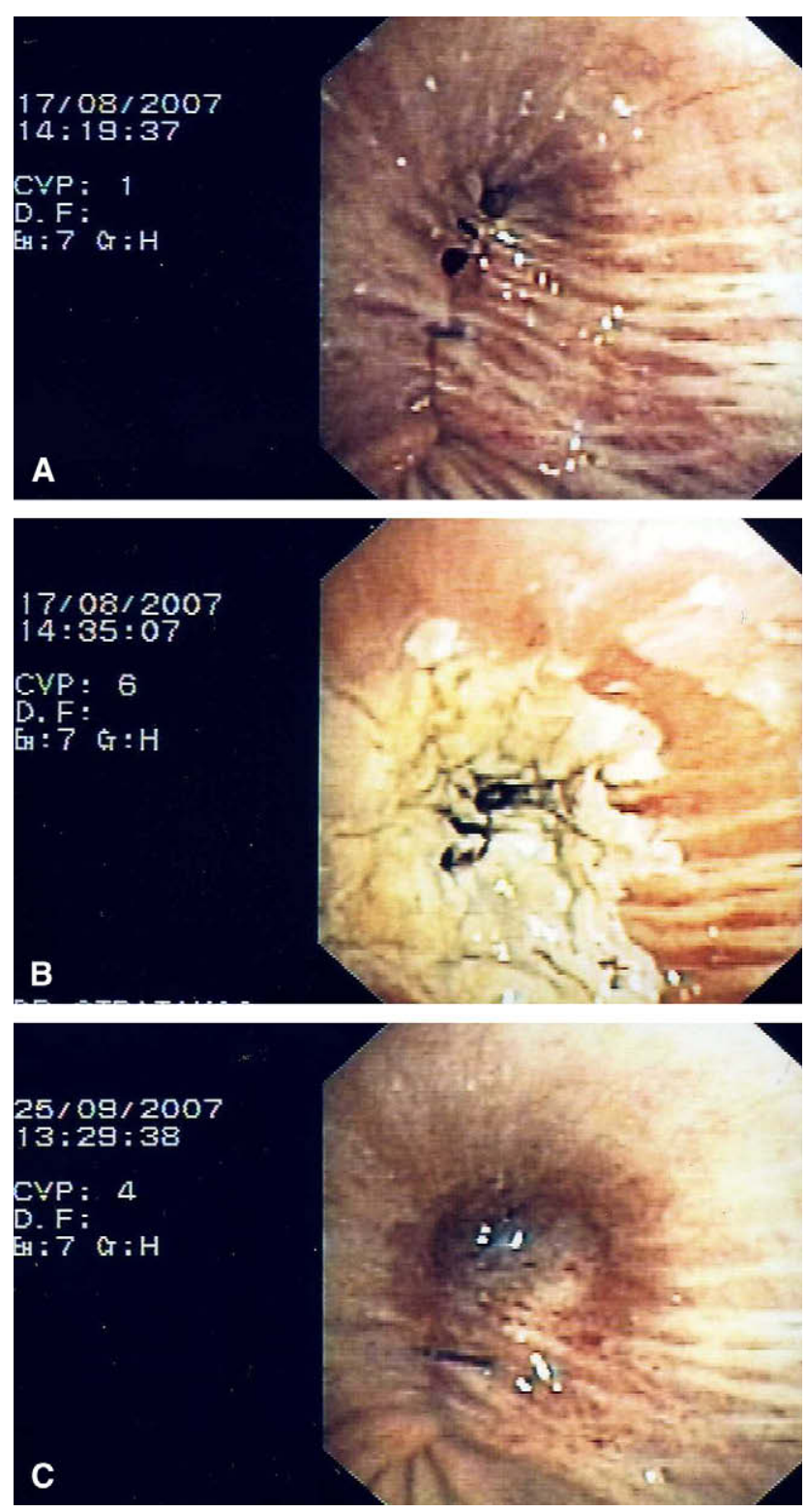

FIGURE 2. A, Dehiscence of the left main bronchus stump producing BPF and pyopneumothorax is observed (case 3). B, Immediate scar formation after application of silver nitrate leads to direct elimination of air leak. C, Complete, uneventful healing of the stump is evident 1 month later.

\section{DISCUSSION}

In patients undergoing resection for lung cancer, risk factors for BPFs include locally advanced cases, residual tumor on the stump, right lung or right lower lobe resection, perioperative fever, steroid use, presence of microbial infection, large diameter $(>25 \mathrm{~mm})$ of the bronchial stump, and concurrent radiation therapy or chemotherapy. ${ }^{2,5}$ BPFs occurring within 1 week of surgery are classified as acute forms and are not necessarily associated with empyema, whereas the subacute or chronic forms are usually associated with bacterial infection of the lung and pleural space. Mortality ranges from $25 \%$ to $67 \%$, the most common cause of death being aspiration pneumonia with subsequent acute respiratory distress syndrome. ${ }^{3,5}$

Sirbu and colleagues ${ }^{2}$ recently published a large series of 490 lung resections for non-small cell lung cancer reporting a $4.4 \%$ overall incidence of BPF, recognizing right pneumonectomy as the main risk factor for the higher incidence $(13.5 \%)$ of this complication. In our series, 7 of 11 patients had right-sided BPF, and 7 of 11 patients had undergone pneumonectomy (Table 1).

Cooper and Miller ${ }^{15}$ recently recommended a stepwise management of patients with BPF. Emergency drainage and proper antimicrobial coverage are required when pneumothorax and empyema are present. Bronchoscopic evaluation of the airways is warranted in all cases. When large major bronchus stump dehiscence is evident, immediate resuture and reinforcement are necessary. Many patients may require consecutive operations and various accesses to achieve a successful result. In the series of Puskas and colleagues, ${ }^{16}$ the patients had already undergone an average of 3.3 surgical procedures to correct their BPF during a mean interval of 24 months before the treatment applied by the authors. Aggressive surgical options, such as open window drainage or thoracoplasty, are often problematic for an already compromised patient. Endoscopic fistula closure is an attractive alternative to avoid major surgical interventions. ${ }^{6}$ However, this procedure needs evaluation of the prerequisites for its application, under which circumstances, to whom, and when.

Several studies have reported on the implantation of different materials in the bronchus through a bronchoscope in an attempt to stop the air leak. Materials used have included Gelfoam, doxycycline, blood, fibrin glue, vascular occlusion coils, endobronchial valves, tissue glues, sclerosing agents, human spongiosa, gelatin-sponge particles, lead plugs, balloons, absolute ethanol, or laser beam inducing scar formation. ${ }^{5}$ West and colleagues, ${ }^{7}$ in a recently published best evidence topic, identified 85 cases of post-pneumonectomy BPFs reported in the literature to have undergone bronchoscopic procedures to attempt repair, with an approximate cure rate of $35 \%$ for BPFs $5 \mathrm{~mm}$ or less. In the light of these data, our finding of an $82 \%$ successful treatment rate for BPFs $5 \mathrm{~mm}$ or less is encouraging. Silver salts have antiseptic and cauterizing properties and have recently been used successfully for pleurodesis in humans. ${ }^{17,18}$ Application of silver nitrate causes tissue burn and local inflammation followed by normal healing process and scar formation. Høier-Madsen and colleagues ${ }^{14}$ applied silver nitrate to 10 patients with BPF after pneumonectomy for non-small cell lung cancer through the rigid bronchoscope. The application of silver nitrate destroyed the epithelium in the bronchial stump and induced granulation, achieving the closure of the fistula in all surviving patients. However, no details were given on the exact technique used, and complete 
presentation of the treated cases and their follow-up were not reported.

In our study, the results of local application of this caustic material with the described technique on the mucosa of the BPF orifice were encouraging. All patients were treated by flexible videobronchoscope under only conscious sedation, thus avoiding major interventions and general anesthesia. In most treated patients, effective and uneventful closure of the fistula was accomplished, resulting in dramatic improvement of clinical status. Two cases in which failure to seal the fistulae was noted were subacute forms of BPF in which we intervened within 15 days after surgery. It is likely that this early intervention resulted in the inability to produce cicatricial tissue to seal the communication. It is probable that treatment should be better attempted at least 1 month after surgery when the scar tissue is well organized and the possibility to induce further healing and granulation is higher.

\section{Study Limitations}

The small number of patients with BPFs recruited for bronchoscopic treatment is a study limitation. It should be noted, however, that the small number of patients is partly the result of restricted inclusion and exclusion criteria, mainly the criterion mandating treatment trial in BPFs of small size $(\leq 5 \mathrm{~mm})$. This criterion was included because BPFs of this size have a higher possibility of cure by bronchoscopic techniques according to previously published experience. $^{3-6}$

Another limitation is the absence of a control group of patients with BPFs of similar size treated with another bronchoscopic technique or even with surgical procedures. This limitation is, however, inherent to the small number of patients included, making the design of a control study impossible.

Another possible limitation is the number of bronchoscopic applications of silver nitrate required to attain healing of the fistula. In most cases in our series, several applications have been used (2-10) until complete and definitive closure of the fistula was achieved. The need for repeated bronchoscopic treatment can hardly be foreseen and is mainly based on subjective evaluation of the attained results by the endoscopist. However, no complications or other sequelae have been noted because of the repeated bronchoscopic treatment sessions. The risk of detachment of caustic material from the applicator brush is real and warrants extra caution and skill by the endoscopist to prevent and manage.

It is possible that wider use of the method will generate initiatives from the industry to manufacture and produce specialized applicators of silver nitrate, which would hopefully render this technique safer and even more efficacious.
An obvious advantage of flexible bronchoscope use compared with rigid bronchoscope use is the higher accessibility for patients not fit for general anesthesia and for physicians not accustomed to the use of the rigid scope.

\section{CONCLUSIONS}

Our study describes a technique using a flexible bronchoscopic brush and silver nitrate application for the treatment of small ( $\leq 5 \mathrm{~mm}$ maximal diameter) BPFs. A high closure rate $(>80 \%)$ was observed in our small patient population. Nevertheless, the ultimate place of bronchoscopic approach in the management of BPFs, and particularly the contribution of our series using silver nitrate application, cannot be determined yet. Further investigation of this technique in larger series is warranted before this question is clearly answered.

\section{References}

1. Cerfolio RJ. The incidence, etiology and prevention of postresectional bronchopleural fistula. Semin Thorac Cardiovasc Surg. 2001;13:3-7.

2. Sirbu H, Bush T, Alecsic I, et al. Bronchopleural fistula in the surgery of nonsmall cell lung cancer: incidence, risk factors and management. Ann Thorac Cardiovasc Surg. 2001;7:330-6.

3. Hollaus PH, Lax F, El-Nashef BB, et al. Natural history of bronchopleural fistula after pneumonectomy: a review of 96 cases. Ann Thorac Surg. 1997;63:1391-7.

4. Cooper WA, Miller JI. Management of bronchopleural fistula after lobectomy. Semin Thorac Cardiovasc Surg. 2001;13:8-12.

5. Lois M, Noppen M. Bronchopleural fistulae: an overview of the problem with special focus on endoscopic management. Chest. 2005;128:3955-65.

6. Hollaus PH, Lax F, Janakiev D, et al. Endoscopic treatment of postoperative bronchopleural fistula: experience with 45 cases. Ann Thorac Surg. 1998;66:923-7.

7. West D, Togo A, Kirk AJB. Are bronchoscopic approaches to post-pneumonectomy bronchopleural fistula an effective alternative to repeat thoracotomy? Interactive Cardiovasc Thorac Surg. 2007;6:547-50.

8. Han X, Wu G, Li Y, et al. A novel approach: treatment of bronchial stump fistula with a plugged, bullet-shaped, angled stent. Ann Thorac Surg. 2006;81:1867-71.

9. Scappaticci E, Ardissone F, Ruffini E, et al. Postoperative bronchopleural fistula: endoscopic closure in 12 patients. Ann Thorac Surg. 2000;69:1629-30.

10. Hoffberger DS, Walsh F, Sommers E, et al. Utilisation of a synthetic absorbable sealant activated by helium cadmium laser bronchoscopy for successful closure of persistent bronchopleural fistula following lobectomy. Chest. 2003;124:290S-1S

11. Kiriyama M, Fujii Y, Yanakawa Y, et al. Endobronchial ND-YAG laser for noninvasive closure of small proximal bronchopleural fistula after lung resection. Ann Thorac Surg. 2002;73:945-9.

12. Varoli F, Roviaro G, Grignani F, et al. Endoscopic treatment of bronchopleura fistulae. Ann Thorac Surg. 1998;65:807-9.

13. Takaoka K, Inoue S, Ohira S. Central bronchopleural fistulae closed by bronchoscopic injection of absolute ethanol. Chest. 2002;122:374-8.

14. Høier-Madsen K, Schulze S, Møller Pedersen V, Halkier E. Management of bronchopleural fistula following pneumonectomy. Scand J Thorac Cardiovasc Surg. 1984;18:263-6.

15. Cooper WA, Miller JI. Management of bronchopleural fistula after lobectomy Semin Thorac Cardiovasc Surg. 2001;13:8-12.

16. Puskas JD, Mathisen DJ, Grillo HC, Wain JC, Wright CD, Moncure AC. Treatment strategies for bronchopleural fistula. J Thorac Cardiovasc Surg. 1995 109:989-95.

17. Marcheix B, Brouchet L, Renaud C, et al. Videothoracoscopic silver nitrate pleurodesis for primary spontaneous pneumothorax: an alternative to pleurectomy and pleural abrasion? J Cardiothorac Surg. 2007;31:1106-9.

18. Paschoalini Mda S, Vargas FS, et al. Prospective randomized trial of silver nitrate vs talc slurry in pleurodesis for symptomatic malignant pleural effusions. Chest 2005;128:684-9 